\title{
INDONESIA'S COURTS OF INDUSTRIAL RELATIONS: CONTEXT, STRUCTURE, AND A LOOK AT SURABAYA CASES'
}

\section{William Hurst}

\section{Introduction}

Observers and analysts frequently view Indonesia as a country in which workers' rights are few and organized labor is at best a weak social and political force. After a brief period of activism and influence immediately following independence, labor's social and political role did not grow in tandem with the rise of left-wing parties during the 1950s. Following another relatively short period during which labor strengthened its political position under "Guided Democracy," workers were effectively silenced by Suharto almost immediately upon the rise of the New Order in

\footnotetext{
${ }^{1}$ I am grateful to the Fulbright Program and to the University of Texas at Austin for funding in support of my fieldwork. I am deeply indebted to many friends and colleagues for suggestions and advice they offered on drafts of this article, especially: Joshua Barker, Jacques Bertrand, Jeffrey Winters, and Joseph Wong. I remain responsible, of course, for all errors. I also discuss some of the data on Surabaya casesand the concept of judicialization-in: "Nascent Protections in Emerging Giants: Struggles to Judicialize Labor Rights in China and Indonesia," in Law and Development in Middle-Income Countries: Avoiding the Middle-Income Trap," ed. Randall Peerenboom and Tom Ginsburg (New York, NY: Cambridge University Press, 2014), pp. 270-87.
} 
1967. Scholars famously characterized the New Order's framework for controlling labor as "exclusionary corporatism" and "protective repression."

Despite some agitation by unions and labor activists in the early 1990s, this framework held up strongly. After the fall of Suharto in May 1998, however, an opening was created for revisiting this set of restrictive arrangements, and very recently workers and unions have shown some signs of at least a modest political comeback. ${ }^{3}$ All of this has occurred in the context of evolving legal institutions for the protection of workers' rights and the incorporation of labor into the Indonesian polity.

In 2003 and 2004, Indonesia's parliament, the Dewan Perwakilan Rakyat (DPR), made a sharp and somewhat surprising legislative break by passing Law 13.2003, guaranteeing a variety of labor protections, and then Law 2.2004, establishing special courts of labor relations, to be called Pengadilan Hubungan Industrial (hereafter PHI). These special courts were to be established throughout the country and were to function as stand-alone entities in parallel to the regular operations of courts of the first instance (Pengadilan Negeri). ${ }^{4}$

Though the PHI were new venues for adjudicating labor relations, Indonesia had special courts for administrative disputes since the early 1970s. ${ }^{5}$ It now maintains special courts for the adjudication of corruption, issues involving fisheries, and numerous other kinds of cases, ${ }^{6}$ as well as a new constitutional court separate from the Supreme Court. ${ }^{7}$ Other countries in Asia, such as China, have experimented with special courts for cases involving maritime, railroad, and intellectual property issues, ${ }^{8}$ among others. As in many of these other instances, an assumption that stand-alone courts could both better implement evolving labor standards to protect workers and better facilitate the resolution of disputes seems embedded in the logic behind establishing the PHI.

\footnotetext{
${ }^{2}$ Terri L. Caraway, "Protective Repression, International Pressure, and Institutional Design: Explaining Labor Reform in Indonesia," Studies in Comparative International Development 39,3 (2004): 28-49; Vedi R. Hadiz, Workers and the State in New Order Indonesia (London: Routledge, 1997).

${ }^{3}$ See, for example, Sabrina Asril, "Buruh Ancam Mogok Massal dan Boikot DPR" [Workers Threaten Mass Strike and Boycott of Parliament], Kompas, February 19, 2013, at http:/ / nasional.kompas.com/read / 2013/ 02/19/15174586/Buruh.Ancam.Mogok.Massal.dan.Boikot.DPR.?utm_source=WP\&utm_medium=b ox\&utm_campaign=Khlwp], accessed February 19, 2013. Also, among the most frequently observed signs of a comeback are successful pushes to raise the minimum wage in many provinces, which were implemented in late 2012 and early 2013.

${ }^{4}$ Caraway, "Protective Repression"; Hurst, "Nascent Protections."

${ }^{5}$ Adriaan Bedner, "Shopping Forums': Indonesia's Administrative Courts," in New Courts in Asia, ed. Andrew Harding and Penelope Nicholson (London: Routledge, 2010), pp. 209-30.

${ }^{6}$ See, inter alia, David K. Linnan, "Reading the Tea Leaves' in the Indonesian Commercial Court: A Cautionary Tale, but for Whom?"; Mark Cammack, "The Indonesian Human Rights Court"; and Benjamin H. Tayhar, "The Politics of Indonesia's Anti-Corruption Court," all three of these in Harding and Nicholson, eds., New Courts in Asia, pp. 56-80, 178-206, 279-98.

${ }^{7}$ Hendrianto, "Institutional Choice and the New Indonesian Constitutional Court," in ibid., pp. 158-77; Bjön Dressel and Marcus Meitzner, "A Tale of Two Courts: The Judicialization of Electoral Politics in Asia," Governance: An International Journal of Policy, Administration, and Institutions 25,3 (2012): 391-414.

${ }^{8}$ See, for example: Curtis E. Pew, Robert M. Jarvis, and Mark Sidel, "Maritime Courts in the Middle Kingdom: China's Great Leap Seaward," The Maritime Lawyer 11 (1986): 237-71; Li Jian, "Debating the Specialized Intellectual Property Court in the People's Republic of China," Intellectual Property and Technology Law Journal 19,12 (2007): 17-20; Darcey J. Goeltz, "China's Environmental Problems: Is a Specialized Court the Solution?" Pacific Rim Law and Policy Journal 18,1 (2009): 155-87.
} 
Though full implementation of Law 2.2004 was delayed by executive order, ${ }^{9}$ PHIs had been established across the archipelago in Jakarta, Surabaya, Makasar, Medan, Palembang, Tanjung Pinang, Bandung, Serang, Tanjung Karang, Pekanbaru, Yogyakarta, and-at least in theory-also established in conjunction with every Pengadilan Negeri located in the capital city of a province or in a locality deemed by the president to be an essential center of industry, by early $2006 .{ }^{10}$ Perhaps not surprisingly, workers began filing suits as soon as these venues became available, though in some places-including Jakarta-courts were established late or experienced substantial problems in their early functioning. ${ }^{11}$ Many cases were also transferred into the new PHI from the so-called P4 (Panitia Penyelesaian Perselisihan Perburuhan) system, Indonesia's previous labor dispute resolution venue. Observers and advocates began drawing conclusions about the efficacy of PHIs almost as soon as they came into being, often noting their slow and cumbersome judicial process. ${ }^{12}$

Little systematic research on the PHI has been completed to date. The International Labor Office (ILO) supported a pro-union Indonesian NGO in compiling a number of decisions from PHIs across Indonesia from 2006 and 2007, which it then grouped and analyzed by the issues at stake and the rationale employed by the court. ${ }^{13} \mathrm{~A}$ scholar of Indonesian economic law delivered a conference paper in 2007 that nicely laid out the legal basis for the PHIs and their rules of procedure, before going on to present a variety of cases from 2006 related to each of the major issue areas PHIs are empowered to adjudicate. ${ }^{14}$ But so far, no one has published full results of research based on comprehensive quantitative data examining which sorts of suits have been filed in particular courts or what decisions have been issued around the country, though substantial data collection work in this area has been completed. ${ }^{15}$ Also, because the NGO report and conference paper noted above cover only 2006 and 2007, it is possible that things may have changed in the years since, though more recent analysis shows patterns similar to those evident in 2006 and 2007. ${ }^{16}$ Only one PHI-the Bandung court

\footnotetext{
${ }^{9}$ Peraturan Pemerintah Pengganti Undang-Undang Republik Indonesia [Government Regulation in Lieu of Law] No. 1 (2005); Erman Rajagukguk, "The New Indonesian Labour Court," paper presented at the Conference on New Courts in the Asia-Pacific Region, Melbourne, Australia, July 2007, pp. 1-2.

${ }^{10}$ Undang-Undang Nomor 2 Tahun 2004 tentang Penyelesaian Perselisihan Hubungan Industrial [Law No. 2, 2004, Regarding the Settlement of Industrial Relations Disputes, or UU No. 2/ 2004], Bab III, Pasal 59; Febrianti, "Ketua MA Resmikan 33 Pengadilan Hubungan Industrial" [Chief of the Supreme Court Opens 33 Courts of Industrial Relations], Tempo, January 14, 2006, at http: / / www.tempo.co/ read/news/2006/

01/14/05572305/Ketua-MA-Resmikan-33-Pengadilan-Hubungan-Industrial, accessed September 22, 2012; Surya Tjandra and Marina Pangaribuan, Kompilasi Putusan Pengadilan Hubungan Industrial Terseleksi, 20062007 [Compilation of Selected Decisions of Courts of Industrial Relations, 2006-2007] Jakarta: Trade Union Rights Centre, 2007).

11 Thoso Priharnowo, "Pengadilan Industrial Menunggu Hakim" [Industrial Courts Await Judges], Tempo, February 10, 2006, at http:/ / www.tempo.co/read/news/2006/02/10/05573773/Pengadilan-IndustrialMenunggu-Hakim, accessed September 24, 2012.

${ }^{12}$ See, for example, Marsen Sinaga Pengadilan Perburuhan di Indonesia [Labor Courts in Indonesia] (Yogyakarta: Perhimpunan Solidaritas Buruh, 2006), pp. 74-75.

${ }^{13}$ Tjandra and Pangaribuan, Kompilasi Putusan.

${ }^{14}$ Rajagukguk, "The New Indonesian Labour Court."

${ }^{15}$ Teri L. Caraway, "Final Report: Labor Courts in Indonesia," AFL_CIO paper, available at http: / / www aflcio.org/content/download/28061/347451/version/1 / file/caraway.pdf, accessed March 1, 2013.

${ }^{16}$ Ibid.
} 
with jurisdiction over West Java-has made even basic statistical data freely available, and these only run up through mid-2009.

This article aims to fill some of the gap in extant scholarship. After placing the PHIs in historical and institutional context, I examine, based on field research in Surabaya's PHI in 2010, which included both a compilation of statistical and basic data and an indepth reading of selected case files, the patterns and dynamics underlying the PHIs' decision-making. Lawmakers and elites appear to have established the PHIs to promote the judicialization of labor rights in Indonesia. ${ }^{17}$ Plaintiffs may seek strategically to engage in a variant of what is often termed "forum shopping." The PHI themselves then sometimes must compete with other institutions to assert their authority. Alternatively, the PHI can appear incompetent, wary, or confused in dealing with certain cases. No pattern appears with complete consistency, but the consequences of the disjuncture between competing logics, as well as the gulf between clear motivations and messy reality, require further exploration and explanation.

\section{Indonesia's Courts of Industrial Relations: Context and Structure}

\section{Context}

The PHI were created to replace the Panitia Penyelesaian Perselisihan Perburuhan (P4) system, which had been in existence almost as long as the Republic of Indonesia itself. P4 organs were not courts, but their decisions had the same force of law as decisions issued by the Pengadilan Negeri. ${ }^{18}$ Following a period of intense labor unrest during the post-World War II period and immediately after independence was secured in 1949, Indonesia's military moved to prohibit strikes in sectors of national interest and threatened harsh penalties against unauthorized strikers. ${ }^{19}$ But the government still saw a need for a new legal and institutional framework.

The P4 system was established by Emergency Law 16.1951, explicitly intended to deal with collective actions (tindakan) by workers or managers (i.e., strikes and lockouts). ${ }^{20}$ It also specified the institutional structure of regional (P4Daerah) and central (P4Pusat) P4 organs, noting that P4D should be established in all regions deemed necessary by the Ministry of Labor, with rules of operation set by the Ministry of Labor and staff drawn from the ministries of labor, interior, finance, communications, economics, agriculture, and public works. ${ }^{21}$ The P4D were to have the power to intercede and promote resolution of any and all labor disputes that could not be resolved by mutual agreement of the parties. Workers and management were also required to seek written permission from the $\mathrm{P} 4 \mathrm{D}$ before initiating any strike or lockout. Section 4 of the law prohibited any action from being taken for a minimum of

\footnotetext{
${ }^{17}$ Kosuke Mizuno, "The Rise of Labor Movements and the Evolution of the Indonesian System of Industrial Relations," The Developing Economies 43,1 (March 2005): 191; Hurst, "Nascent Protections."

${ }^{18}$ Sri Hajati, Sri Handajani, Machsoen Ali, M. Zaidun, and Naniek Endang Wrediningsih, Peranan Panitia Penyelesaian Perselisihan Perburuhan dalam Menangani Perselisihan Perburuhan (Surabaya: Lembaga Penelitian Universitas Airlangga, 1985), p. 41.

${ }^{19}$ Peraturan Kekuasaan Militer Nomor 1 Tahun 1951.

${ }^{20}$ Undang-Undang Darurat Nomor 16 Tahun 1951 tentang Penyelesaian Perselisihan Perburuhan, Pasal 1.

${ }^{21}$ UU. Darurat 16/1951, Pasal 1 and 3.
} 
three weeks after the P4D had been informed by those involved (the P4D was required also to inform the Ministry of Labor and the $\mathrm{P} 4 \mathrm{P}$, either of which, in turn, could extend the three-week waiting period). ${ }^{22}$ The $\mathrm{P} 4 \mathrm{D}$ were also empowered to establish panels (panitia enquete) to investigate further disputes of national interest and were tasked with reporting to central authorities why attempts at resolution failed and whether any strikes or other actions took place. ${ }^{23}$

Several years later, after Indonesia's first parliamentary elections, the government reinforced key provisions of the Emergency Law, formalized the P4 process, and clarified the roles of the P4D and P4P, by enacting Law 22.1957. This law required that both parties attempt to resolve any labor disputes and stressed that both had a duty to seek mediation or arbitration as a first step if they could not reach agreement. ${ }^{24}$ Section 5 established clear guidelines on the representation of various bureaucratic interests in the $\mathrm{P} 4 \mathrm{D}$ 's structure, while section 6 required that the $\mathrm{P} 4 \mathrm{D}$ be informed of any group's intent to engage in a lockout, or especially to strike, and gave the head of the P4D a deadline of seven days to accept such a notification. Only after receiving the P4D chair's letter of acceptance could workers strike legally, ${ }^{25}$ though such acceptance letters were, in fact, rarely ever issued in practice. ${ }^{26}$

Under Guided Democracy in 1964, Indonesia's Gotong-Royong Parliament enacted Law 12.1964. The main point of this statute was explicitly to extend the P4 system governing dismissals (pemutusan hubungan kerja, or PHK) to private firms. Employers were forbidden to dismiss workers absent from their posts for up to twelve months if the absences were attributed to religious duties or illness (and, also, to excuse them indefinitely for any form of national service). ${ }^{27}$ Also, before dismissing anyone, an employer had to inform the employee and union (if any) of the intended dismissal and the reasons behind it, before seeking formal permission from the P4D (or the P4P in the case of any intended "mass dismissal" of ten or more employees in a month). ${ }^{28}$ The only exception was for dismissing workers during the probationary period (masa percobaan) of their first three months on the job. ${ }^{29}$ All cases involving dismissals were to follow the basic P4 process established in Law 22.1957, with the important new provision that either side could appeal a decision of the P4D to the P4P within two weeks of receipt. ${ }^{30}$ Together, this body of legislation established a labor dispute resolution system under control of the government (especially the Ministry of Labor), reined in workers' right to strike, and required employers to obtain formal government permission to dismiss workers. ${ }^{31}$

\footnotetext{
${ }^{22}$ Ibid., Pasal 4.

${ }^{23}$ Ibid., Pasal 6-11.

${ }^{24}$ Undang-Undang Nomor 22 Tahun 1957 tentang Penyelesaian Perselisihan Perburuhan, Pasal 2 and 3.

${ }^{25}$ Ibid., Pasal 5 and 6.

${ }^{26}$ Mizuno, "The Rise of Labor Movements," p. 198.

${ }^{27}$ Undang-Undang Nomor 12 Tahun 1964 tentang Pemutusan Hubungan Kerja di Perusahan Swasta, Pasal 1.

${ }^{28}$ Ibid., Pasal 2 and 3.

${ }^{29}$ Ibid., Pasal 4.

${ }^{30}$ Ibid., Pasal 8.

${ }^{31}$ Rita O. Tambunan, Surya Tjandra, and Jafar Suromenggolo, "A Review of Indonesian Labour Law," in Asia Pacific Labour Law Review: Workers' Rights for the New Century, ed. Stephen Frost, Omana George, and Ed Shepard (Hong Kong: Asia Monitor Resource Centre, 2003), available at http: / www.amrc.org.hk/
} 
Relatively little has been published on the P4 system's operation. The Indonesian Employers' Association (Perhimpunan Urusan Sosial-Ekonomi Pengusaha Seluruh Indonesia, PUSPI) published a guide to the P4 system in 1983, mainly explaining the P4D and P4P structure and providing examples of letters and other documents for employers seeking to bring dismissal-related and other cases before the tribunals. ${ }^{32} \mathrm{~A}$ group of researchers from Airlangga University in Surabaya published an academic study of the P4 system two years later, in $1985 .{ }^{33}$ They made the astute observation that, although the main role of the P4D was to determine whether or not to grant employers permission to dismiss workers, their decisions were often bound up with issues of hak and kepentingan (terms sometime translated as "contracts" and "conditions," ${ }^{34}$ but better understood more literally as "rights" and "interests" or "standing"). ${ }^{35}$ That is, when determining whether an employer may dismiss a particular worker, the P4D also had to rule first on whether that worker (or his/her union) had the authority to negotiate, and then on the question of what the worker might be entitled to in contractual and legal terms.

Perhaps most useful is a series of decision documents from several years during the 1970s, published in two volumes by the Manpower Bureau for South and Central Kalimantan in $1979 .{ }^{36}$ The pattern of these decisions bears out the conventional wisdom, stated explicitly by the Employers' Association, that the vast majority of cases heard by the P4D were concerned with dismissals (PHK). ${ }^{37}$ What is interesting, however, is that most of the cases seem to have been initiated by employers seeking to dismiss workers (rather than by workers challenging dismissals). There was apparently a great range in terms of the severance and other benefits awarded to dismissed workers by the P4 process. As we can see from Table 1, the total number of cases filed each year during the 1970s hovered around twenty to thirty-five, much fewer than the total of cases filed in the Surabaya or Bandung PHI in the late 2000s (though one can imagine the P4D in East or West Java was likely also busier in the 1970s than its South/Central Kalimantan counterpart).

Nearly all the decisions involved PHK cases and a high proportion of the cases involved a handful of employers-mostly in Banjarmasin, but also involving workers in lumber, mining, and timber companies from Batu Licin and Kota Baru to Sampit and Palangkaraya, and even the employees of a Korean investment and development firm. Certain firms, such as a Chinese-Indonesian owned trading company in Banjarmasin, seemed frequently able to dismiss workers without paying severance or

node/1182, accessed February 3, 2014. See also http: / / www.amrc.org.hk/system/ files / Indonesia.pdf, pp. 4-5, accessed February 3, 2014.

${ }_{22}$ PUSPI, Panitia Penyelesaian Perselisihan Perburuhan dan Permasalahanya [The P4 and Their Problems] (Jakarta: PUSPI, 1983).

${ }^{33}$ Sri Hajati et al., Peranan P4.

${ }^{34}$ Hurst, "Nascent Protections."

${ }^{35}$ Sri Hajati et al., Peranan P4, pp. 44-45.

${ }^{36}$ Departamen Tenaga Kerja dan Transmigrasi Kantor Wilayah Dit. Jen. Pembinaan Hubungan Perburuhan dan Perlindungan Tenaga Kerja Kalimantan Selatan/Tengah Kodifikasi Putusan P4 Daerah Kalimantan Selatan dan Tengah (Banjarbaru: Proyek Pengurusan Persyaratan Kerja dan Pengupahan, 1979 80).

${ }^{37}$ PUSPI, P4 dan Permasalahannya, p. 2. 
having to prove that the workers had acted improperly. Other companies, especially plywood and rubber factories, as well as a Banjarmasin nightclub that repeatedly appeared before the $\mathrm{P} 4 \mathrm{D}$, seemed most often required to make particularly high severance and other payments to dismiss workers. Perhaps most striking, however, was that employers seeking permission to dismiss workers initiated the great majority of cases, as noted above. Relatively few claims seem to have been lodged by workers challenging their dismissal-and most claims workers did make were decided with curt letters validating (mengesahkan) dismissals the P4D deemed covered by a prior mutual agreement.

\section{Table 1: Summary of Decisions by the P4D for Kalimantan Selatan and Tengah, Banjarbaru (years for which data was available)}

\begin{tabular}{|c|c|c|c|c|c|c|}
\hline Year* & $\begin{array}{l}\text { Total number of } \\
\text { cases (imputed } \\
\text { from decisions } \\
\text { recorded through } \\
\text { at least December } \\
20 \text { of each year) }\end{array}$ & $\begin{array}{c}\text { Number of } \\
\text { cases in which } \\
\text { a clear } \\
\text { decision was } \\
\text { reached }\end{array}$ & $\begin{array}{c}\text { Number } \\
\text { of PHK } \\
\text { cases }\end{array}$ & $\begin{array}{c}\text { Number of } \\
\text { cases } \\
\text { clearly } \\
\text { initiated by } \\
\text { employer }\end{array}$ & $\begin{array}{c}\text { Number of } \\
\text { cases } \\
\text { decided in } \\
\text { employer's } \\
\text { favor }\end{array}$ & $\begin{array}{c}\text { Number of } \\
\text { cases requiring } \\
\text { severance (or, in } \\
\text { parentheses, } \\
\text { lesser } \\
\text { compensation }^{38} \text { ) } \\
\text { be paid to } \\
\text { employee }\end{array}$ \\
\hline 1972 & 22 & 22 & 22 & 0 & 0 & $(1)^{39}$ \\
\hline 1973 & 16 & 11 & 11 & 9 & 9 & $6(2)$ \\
\hline 1975 & 22 & 13 & 13 & 12 & 12 & $5(2)$ \\
\hline 1976 & 26 & 23 & 23 & 19 & $17^{40}$ & $7(4)$ \\
\hline 1977 & 21 & 20 & 18 & 18 & 18 & $9(2)$ \\
\hline 1978 & 34 & 34 & 34 & 34 & $33^{41}$ & $11(2)$ \\
\hline
\end{tabular}

* Year 1974 is intentionally absent due to lack of data.

Three cases stand out especially from the others: one in which the P4D went through the enquete process and two in which labor unions pressed claims for back

\footnotetext{
${ }^{38}$ Other compensation may include, for instance, medical, relocation, and housing expenses, as well as payment for years of service, known as "cuti tahunan."

${ }^{39}$ In one case, the employer (ironically called PT. Gotong Royong, or "Mutual Assistance, Inc.") was ordered to pay dismissed employees the greater of one month of salary or Rp.3000 in order to "memberikan good will."

${ }^{40}$ In one case, the P4D ruled that a Banjarmasin pharmacy had unfairly changed its expectations of five workers and thus could not fire them legitimately. In another case, the P4D was unable to decide a case right away and moved to establish a "panitia enquete." This panel reported back, and two weeks later the P4D issued a nominally separate decision in favor of the Banjarmasin employer.

${ }^{41}$ In one case, a lumber company had submitted paperwork meant for dealing with permanent employees to support its request to dismiss a contract worker. The P4D advised that, upon receipt of the correct paperwork, permission to dismiss the worker would be granted.
} 
wages owed to members working at a food warehouse and a construction firm engaged in irrigation projects. In the enquete case, the P4D sought to determine whether a worker had embezzled funds from his Banjarmasin employer and appointed a panel of four people (including one lawyer) to investigate and report back within a week. ${ }^{42}$ Two weeks later, the P4D decided that the worker could indeed be dismissed for misconduct, though he was still entitled to a severance payment equal to six days' wages (Rp.9600). ${ }^{43}$ In the case of the construction workers, the P4D found that they were indeed entitled to payments of between Rp.1200 and Rp.9600 each, which their employer had to pay immediately. ${ }^{44}$ The P4D decided in a more complex case that, although the food warehouse workers had been sent to work at a new location, they were still employees under their original supervisor, who had a duty to ensure they were paid for all days worked. The matter of back wages for the time spent adjudicating their case was referred back to Manpower Bureau authorities in Banjarmasin. ${ }^{45}$ That unions and workers do not seem to have filed more of these contractual-type claims speaks to the likely difficulty of doing so and the uncertainty of winning any restitution via the $\mathrm{P} 4$ process. Other scholarship also suggests that the P4D were ineffective at promoting workers' interests and generally served as tools for the government to issue permission to employers for dismissals while reining in strike activity. ${ }^{46}$

The foundations of Indonesian labor law and the P4 system came into question with the collapse of the New Order. Despite an initially moribund response by labor to this opportunity, ${ }^{47}$ the debate quickly shifted in ways that were at least superficially in workers' favor. ${ }^{48}$ The promulgation of Order Number 150 (Keputusan Menteri Tenaga Kerja Republik Indonesia, No. Kep-150/Men/2000, commonly referred to simply as "Kep$\left.150^{\prime \prime}\right)$ in June of 2000 by then-Minister of Manpower Bomer Pasaribu was a key event. ${ }^{49}$ This edict clarified many aspects of prior labor law, establishing strict criteria for when and how workers could be dismissed with cause, better specifying procedures for employers to obtain permission to dismiss workers, and laying down clearer formulae for calculating severance pay and other benefits due to dismissed workers. ${ }^{5 i}$

Law 13.2003 expanded on the reforms of Kep-150, regulating everything from required job training, to the use of foreign workers, to the welfare provisions different categories of workers are entitled to, and the meaning of labor relations. ${ }^{51}$ It spelled out

\footnotetext{
${ }^{42}$ Decision document for case 16/ PHK/ P4D/1976, P4D Kalimantan Selatan/Tengah.

${ }^{43}$ Decision document for case 19/ PHK/P4D/1976, P4D Kalimantan Selatan/Tengah.

${ }^{44}$ Decision document for case 13/M/P4D/1977, P4D Kalimantan Selatan/Tengah.

${ }^{45}$ Decision document for case 21/ M/ P4D / 1977, P4D Kalimantan Selatan/ Tengah.

${ }^{46}$ Mizuno, "The Rise of Labor Movements," pp. 190-211.

${ }^{47}$ Jeffrey A. Winters, "The Political Economy of Labor in Indonesia," Indonesia 70 (October 2000): 148-49; Tim Lindsey and Teten Masduki, "Labour Law in Indonesia after Soeharto: Reformasi or Replay?" in Law and Labour Market Regulation in East Asia, ed. Sean Cooney, Tim Lindsey, Richard Mitchell, and Ying Zhu (London: Routledge, 2002), pp. 47-49.

48 Caraway, "Protective Repression," p. 32

${ }^{49}$ Ibid., pp. 37-39.

${ }^{50}$ Kep-150, Bab II, III, IV.

${ }^{51}$ Undang-Undang Nomor 13 Tahun 2003 tentang Ketenagakerjaan [Law Number 13, 2003, regarding Manpower], Bab V, VIII, IX, X.
} 
clearly the right of workers to form unions, the mechanisms necessary and recommended for these unions to function, and new rules for handling strikes and lockouts. ${ }^{52}$ It also expanded upon and codified regulations laid out in Kep-150 on dismissals and and severance payments. ${ }^{53}$

With the issuance of Kep-150 and Law 13.2003, many of the less clear sections of earlier labor legislation (often seen as most disadvantageous to workers) were overhauled and updated. The handling of labor disputes, however, remained in the hands of a state-controlled P4 system that was seen by many as neither willing nor competent to protect workers' rights adequately or enforce labor rules fairly and efficiently. In this context, and with the aim of improving and depoliticizing labor dispute resolution, the DPR created the PHI system with Law 2.2004.

\section{Structure}

Law 2.2004 established the PHI, set out their mandate and organizational structure, defined where the offices should be established, and specified processes for adjudication of labor disputes from simple bargaining and mediation through to trial. ${ }^{54}$ It also specified the types of suits that could be brought: hak (rights, often related to contractual terms), kepentingan (standing, often in the context of negotiating contracts or terms of employment), pemutusan hubungan kerja (PHK/dismissals), and disputes between trade unions seeking bargaining or representational rights for workers in a given factory (Perselisihan antara Serikat Buruh hanya dalam satu Perusahaan). ${ }^{55}$ This categorization clarified the court's mission and delineated which disputes were actionable ${ }^{56}$ but, importantly, also recognized the need for the PHI to have a broader jurisdictional scope than the P4D (as suggested by the Airlangga researchers back in 1985).

Law 2.2004's Chapter 3 established that the PHI, unlike the P4 panels, were to be staffed by judges, and it set out the qualifications for judges. It also required that at least five ad hoc lay judges be appointed to each PHI from labor unions, along with another five from employers' federations. ${ }^{57}$ This was in sharp contract to the staffing of P4 panels, which were generally filled with government officials from various ministries, and, in practice, it has meant that there has been almost no staffing continuity between the P4 and the new PHI.

\footnotetext{
52 Ibid., Bab XI Pasal 102, 104, 136-49.

${ }^{53}$ Ibid., Bab XII.

${ }^{54}$ UU No. 2/2004, Bab II-IV; Rajagukguk, "The New Indonesian Labor Court," pp. 6-11.

${ }^{55}$ UU No. 2/ 2004, Bab I, Pasal 2; Bab III, Pasal 56; Simon Nahak, "Kewenangan Pengadilan Hubungan Industrial Terhadap Upaya Penyelesaian Perselisihan Hubungan Industrial" [Authority of the Courts of Industrial Relations in their Efforts to Resolve Industrial Relations Disputes], Kertha Wicaksana 15,1 (2009): 73-82.

${ }^{56}$ Sri Subiandini Gultom, Aspek Hukum Hubungan Industrial [Aspects of Industrial Relations Law] (Jakarta: Inti Prima Promosindo, 2008), pp. 61-63.

${ }^{57}$ UU No. 2/ 2004, Bab III, Pasal 70. On the important roles of ad hoc and lay judges in many areas of Indonesian jurisprudence, including criminal justice, see, for example: Luhut M. P. Pangaribuan, Lay Judges dan Hakim Ad Hoc: Suatu Studi Teoretis Mengenai Sistem Peradilan Pidana Indonesia [Lay and Ad Hoc Judges: A Theoretical Study about Indonesia's Criminal Adjudication System] (Jakarta: Papas Sinar Sinanti and Fakultas Hukum Pascasarjana Universitas Indonesia, 2009).
} 
Chapter 4 of Law 2.2004 established rules of procedure for adjudicating cases in PHIs. ${ }^{58}$ PHIs were to function in a manner similar to the ordinary Pengadilan Negeri, but with several important departures. ${ }^{59}$ Panels of three judges, Majelis Hakim, adjudicate case in the PHI-just as in most Indonesian courts, but in sharp contrast to the P4 panels. But the PHIs' panels are composed of one professional judge (acting as chair, Ketua Majelis Hakim) and two ad-hoc lay judges (one from a labor union, the other from an employers' group, and noticeably none from any administrative arm of the state). ${ }^{60}$ In something of a holdover from the two-level P4 system (in contrast to the three-level regular court system), parties to hak or PHK cases have the right to appeal (kasasi) PHI decisions directly to the Supreme Court (Makamah Agung), without first approaching a higher-level court (Pengadilan Tinggi) at the provincial level. ${ }^{61}$

Procedurally, when considering cases that involve either hak or kepentingan issues alongside PHK, PHIs are obliged to adjudicate those conceptually prior parts of the case first, determining the nature and obligations of the relationship between the two parties, before dealing specifically with the dismissal (following a sequence the Airlangga team suggested in 1985). ${ }^{\circ 2}$ Finally, PHI chairs are required to issue interim judgments (putusan sela) if an employer is found to have failed to pay wages and benefits while the PHI's decision on a worker's dismissal is still pending. ${ }^{63}$ This forces the employer to pay wages while the parties await the final outcome. The P4 system was to give way to the PHI at the end of $2003,{ }^{64}$ but the Presidential Order mentioned earlier delayed full transition to the PHI system until the start of 2006.

\section{Conceptual Lenses for Assessing the Functioning of the PHI}

No conceptual lens from the wider literature is clearly best for analyzing or assessing the PHIs' functioning. Still, there are three prominent perspectives on courts and dispute resolution that may be of value, and at least some cases do, indeed, provide support for each of the three. There are other cases that suggest other, unexpected dynamics may be at work, however.

\section{Judicialization}

Many have characterized efforts to transfer authority from executive or legislative spheres into the realm of courts and legal processes as examples of judicialization. ${ }^{65}$

\footnotetext{
${ }^{58}$ UU No. 2/ 2004, Bab IV.

${ }^{59}$ Ibid., Bab III, Paragraf 2-3; Rajagukguk, “The New Indonesian Labor Court," p. 13.

${ }^{60}$ UU No. 2/ 2004, Bab IV, Pasal 88.

${ }^{61}$ Ibid., Bab IV, Pasal 110.

${ }^{62}$ UU No. 2/ 2004, Bab IV, Pasal 86.

${ }^{63}$ Ibid., Bab IV, Pasal 96; UU No. 13/2003, Pasal 155.

${ }^{64}$ Agriceli-Tempo News Room, "Panitia Penyelesaian Perselisihan Perburuhan Akan Dilikuidasi" [P4 Panels to be Disbanded], Tempo, December 16, 2003, http: / / www.tempo.co/read/ news/2003/12/16/ 05635694/Panitia-Penyelesaian-Perselisihan-Perburuhan-Akan-Dilikuidasi, accessed February 23, 2013.

${ }^{65}$ Alec Stone Sweet, Governing with Judges: Constitutional Politics in Europe (New York, NY: Oxford University Press, 2000); Marin M. Shapiro and Alec Stone Sweet, Law, Politics, and Judicialization (Oxford
} 
The process also involves the development of formal, "triadic" (involving an impartial judge or arbiter in addition to the two parties), dispute-resolution mechanisms to govern a particular set of activities or group of people. ${ }^{66}$ Prominent authors have recently applied and refined this idea in discussions of courts in authoritarian- and developing-country contexts. ${ }^{\sigma}$

Judicialization thus usually entails either the extension of state power into previously unregulated realms of social interaction or state attempts to reduce the degree of direct executive coercion needed to achieve resolution of disputes. Both of these actions strengthen and streamline the state's apparatus of social control, simultaneously bolstering the regime's popular and international legitimacy. To the degree that PHIs have assumed authority over the resolution of labor disputes in some normatively and politically accepted way, becoming and remaining fully independent of executive or legislative branches of the state, we can say that the resolution of Indonesian labor disputes has been judicialized. ${ }^{68}$ This, again, appears to have been a primary goal of creating the PHI system, but it is far from clear that it has been realized.

\section{Forum Shopping}

The concept of forum shopping has a venerable history in American jurisprudence and legal scholarship, dating all the way back to the Supreme Court's landmark 1842 Swift $v$. Tyson ruling. ${ }^{69}$ Forum shopping occurs when different courts can apply substantively different law or reasoning to the same matter, jurisdiction is unclear or malleable, and plaintiffs seek out a forum most favorable to their case. Though the US Supreme Court acted seventy-five years ago to reduce opportunities for forum shopping in the federal courts, ${ }^{70}$ it remains an oft-noticed phenomenon in the United States and beyond.

Oxford University Press, 2002); and Ran Hirschl, Towards Juristocracy: The Origins and Consequences of the New Constitutionalism (Cambridge, MA: Harvard University Press, 2004).

${ }^{66}$ Alec Stone Sweet, "Judicialization and the Construction of Governance," Comparative Political Studies, 32,2 (1999): 164; Martin M. Shapiro, Courts: A Comparative and Political Analysis (Chicago, IL: University of Chicago Press, 1981).

${ }^{67}$ Tom Ginsburg and Tamir Moustafa, eds., Rule by Law: The Politics of Courts in Authoritarian Regimes (Cambridge: Cambridge University Press, 2008); Tom Ginsburg and Albert Chen, eds., Administrative Law in Asia (London: Routledge, 2009); Hualing Fu, "Access to Justice in China: Potentials, Limits, and Alternatives," in Legal Reforms in China and Vietnam: A Comparison of Asian Communist Regimes, ed. John Gillespie and Albert Chen (London: Routledge, 2010), pp. 163-87; John Gillespie,"Exploring the Limits of the Judicialization of Land Disputes in Vietnam," Law and Society Review 45,2 (2011): 24-276; Jonathan Kinkel and William Hurst, "Access to Justice in Post-Mao China: Assessing the Politics of Criminal and Administrative Law," Journal of East Asian Studies 11,3 (2011): 465-98; Hurst, "Nascent Protections."

${ }^{68}$ Hurst, "Nascent Protections."

${ }^{69}$ It is worth recalling that Swift $v$. Tyson applied only to cases in which the "diversity jurisdiction" of the federal courts was invoked (that is, when cases were filed in federal court on the basis of the fact that parties hailed from different states or when a matter occurred in a state where neither party resided). Also, the ruling is unclear as to whether the ruling in Swift $v$. Tyson was meant to apply beyond the narrow set of issues, pertaining to financial instruments, addressed in the original case. It was used as a basis, however, for countless attempts at forum shopping in the United States for nearly a century.

${ }^{70}$ Its ruling in the 1938 case of Erie Railroad Company $v$. Thomkins is usually taken as the critical turning point. 
Many have noted that policy entrepreneurs and other advocates seek out the most favorable forum for pressing their agendas. ${ }^{71}$ Others have argued more generally that organizations, to the extent permitted, search for venues they perceive to be favorably disposed to their particular issues or preferences. ${ }^{72}$ Some have even applied the concept to trade disputes and other international negotiations. ${ }^{73}$ Even where jurisdiction and rules are clear, opportunities for forum shopping persist-for example, when individuals select specific queues or officers for immigration, motor vehicle, or customs processing-and they extend, famously, to decisions over when, where, and how to file bankruptcy cases. ${ }^{74}$

Forum shopping in Indonesian labor disputes should be easy to identify, but also relatively rare, as rules and jurisdiction are clear. If we see clusters of particular types of cases in specific venues, this could suggest forum-shopping behavior. More importantly, if different courts or adjudication bodies appear to be applying substantively different legal standards or procedures, this could show that the system is at least potentially open to such strategic choices of venue. Also, the fact that the resolution of labor disputes can take place in any of three stages-Manpower Bureau arbitration, the PHI, and on appeal to the Supreme Court-almost requires parties to be strategic about how they pursue their cases at each stage (which is not exactly forum shopping, but certainly can amount to differential presentation across several venues).

\section{Bureaucratic Competition}

Bureaucratic competition involves contestation over political or regulatory power by agencies or institutions with overlapping jurisdictions or authority. This condition can produce a variety of outcomes, from political paralysis to heightened efficiency, but it always entails a struggle between rival bureaucratic actors for control over some aspect of state power. Recently, many scholars of Chinese politics have deployed this concept to describe a variety of phenomena.

Andrew Mertha and Douglas Grob have found bureaucratic competition improving governance and promoting Chinese legal development. In his study of copyright and intellectual property enforcement, Mertha found that rival Chinese agencies competed in what he calls "policy enforcement markets" for the authority to rein in counterfeiters and makers of pirated goods. ${ }^{75}$ Grob, meanwhile, found tensions between the horizontally linked legal affairs office (fazhiban) at each level of

\footnotetext{
${ }^{71}$ See, for example, Frank R. Baumgartner, Bryan D. Jones, and Michael C. MacLeod, "The Evolution of Legislative Jurisdictions," The Journal of Politics 62,2 (2000): 323.

${ }^{72}$ See, for example, Sarah B. Pralle, "Shopping Around: Environmental Organization and the Search for Policy Venues," in Advocacy Organization and Collective Action, ed. Aseem Prakash and Mary Kay Gugerty (Cambridge: Cambridge University Press, 2011), pp. 177-202.

${ }^{73}$ See, for example, Marc L. Busch, "International Institutions, Forum Shopping, and Dispute Settlement in International Trade," International Organization 61,4 (2007): 735-61.

${ }^{74}$ Lynn M. LoPucki and William C. Whitford, "Venue Choice and Forum Shopping in the Bankruptcy Reorganization of Large, Publicly Held Companies," 1991 Wisconsin Law Review (1991): 13.

${ }^{75}$ Andrew C. Mertha, "Policy Enforcement Markets: How Bureaucratic Redundancy Contributes to Effective Intellectual Property Implementation in China," Comparative Politics 38,3 (2006): 295-316.
} 
government (which sought to protect local government interests) and the corresponding, vertically controlled, justice bureau (sifating), which aimed to implement central edicts to popularize legal consciousness and empower the citizenry. ${ }^{76}$

Students of Indonesian politics have noted increasing bureaucratic competition since reforms enhanced local autonomy (otonomi daerah) at the end of the 1990s. This development, however, has almost always been seen as opening new avenues for corruption and malfeasance, thus weakening an already less-than-capable state apparatus at the subnational level. ${ }^{77}$ Decentralization empowers local elites to influence policy implementation and weakens direct links between citizens and the central state. The loosening of top-down principal-agent authoritarian control provides new tools and tactics to local leaders seeking to undermine, exploit, or plunder the local state apparatus. Overall, such bureaucratic competition is more reminiscent of Joel Migdal's pernicious "triangle of accommodation" 78 than of Mertha's virtuous "policy enforcement markets."

If we find PHIs squabbling with Manpower Bureaus or other courts or arbitrators for authority to adjudicate labor disputes, this would suggest bureaucratic competition. This dynamic may be strengthened by provisions of Law 2.2004 that allow for, even encourage, the use of a variety of dispute resolution mechanisms outside of the PHI (called penyelesaian perselisihan di luar pengadilan) ${ }^{79}$ To the extent that PHIs are following a virtuous pattern of bureaucratic competition, we should see their contests with other agencies or institutions producing enhanced protections for workers or more efficient implementation of the labor law. To the extent that they follow a more insidious pattern, we should see heightened corruption or mishandling of justice, exacerbated by the extra steps aggrieved workers must take to navigate the new institutions and processes.

\section{Something Completely Different?}

It is certainly possible-even likely-that none of the above three logics may be at work in the majority of cases brought before the PHI. For example, PHIs could simply ignore the demands of workers and even managers, taking only the most minimal actions when forced to intervene. A particular PHI may also have been so corrupted through bribery or other more subtle mechanisms that the forum has become systematically biased. It could also be that PHIs lack the competence, either in terms of staff and resources or in terms of knowledge and expertise, to adjudicate many cases

\footnotetext{
${ }^{76}$ Douglas B. Grob, "Legalizing the Local State: Administrative 'Legality' at China's Grassroots," in Chinese Justice: Civil Dispute Resolution in Contemporary China, ed. Margaret Y. K. Woo and Mary E. Gallagher (Cambridge: Cambridge University Press, 2011), pp. 91-113.

${ }^{77}$ See, inter alia: Vedi R. Hadiz, "Reorganizing Political Power in Indonesia: A Reconsideration of Socalled 'Democratic Transitions,"' in Regionalism in Post-Suharto Indonesia, ed. Maribeth Erb, Priyambudi Sulistiyanto, and Carole Faucher (London: Routledge, 2005), pp. 36-53; Lorraine V. Aragon, “Elite Competition in Central Sulawesi," in Renegotiating Boundaries: Local Politics in Post-Suharto Indonesia, ed. Henk Schulte Nordholt and Gerry van Klinken (Leiden: KITLV Press, 2007), pp. 39-66.

${ }^{78}$ Joel S. Migdal Strong Societies and Weak States: State-Society Relations and State Capacities in the Third World (Princeton, NJ: Princeton University Press, 1988).

${ }^{79}$ Nakak, "Kewenangan Pengadilan Hubungan Industrial," pp. 77-81.
} 
before them promptly and in accordance with the relevant statutes. Thus, even while looking for evidence of the three logics above, it is important to remain open to the possibility that other factors could be equally or even more important.

\section{Data and Analysis}

During March 2010, I received basically unfettered access to the archives of Surabaya's PHI. With a population of roughly three million in the city (and another twenty-five million in the PHI's area of jurisdiction), Surabaya is the core of Indonesia's second-largest conurbation, its largest industrial center outside Jakarta (and the most manufacturing-intensive region), home of the naval headquarters, and gateway to the eastern two-thirds of the country. It is thus a critical case for assessing the new PHI system.

The Surabaya PHI began accepting cases in 2006 and saw an increasingly heavy caseload through to at least the end of 2009. Examining basic records of all cases filed since the court opened is a crucial first step to understand how this organization functioned. Teasing out processes and mechanisms at work requires the analysis of individual files in more detail.

\section{Trends Seen in Quantitative Data on Surabaya Cases}

In March 2010, I was able to compile basic data on all cases brought before Surabaya's PHI. All Indonesian courts keep "registers," usually hand-written ledger books roughly $80 \mathrm{~cm} \times 40 \mathrm{~cm}$ in size, in which the type of case, first outcome, and subsequent appellate action are meant to be recorded. These vary greatly in quality and comprehensiveness. Most registers are destroyed (euphemistically termed "sent to the warehouse," "masuk gudang") after about five years. Surabaya's PHI is small and staffed by professional and committed judges and clerks (at least some of whom specifically asked to be transferred from the prestigious and centrally located Pengadilan Negeri to the newly created PHI, housed in a cramped and substandard building on a side lane in a working class area near the major industrial areas around the Purabaya/Bungurasih Bus Terminal at the Southern edge of the city, close to the border with Sidoarjo Regency).

Not all PHI are physically separate from the Pengadilan Negeri. In many smaller provinces, the PHI simply occupies an office inside the regular court and uses ordinary hearing rooms for its proceedings. In North Sulawesi, for example, the main PHI for the province maintains a roughly ten-square-meter office with a staff of three inside Manado's Pengadilan Negeri. 
Table 2: Basic Data on Surabaya PHI Cases, 2006-09

\begin{tabular}{|c|c|c|c|c|c|}
\hline & 2006 & 2007 & 2008 & 2009 & $\begin{array}{c}\text { Total } \\
2006-09\end{array}$ \\
\hline Total cases filed & 192 & 242 & 264 & 274 & 972 \\
\hline Total hak cases & $9^{* * *}$ & 33 & $36^{* * *}$ & 28 & 106 \\
\hline $\begin{array}{l}\text { Number in which decision } \\
\text { known (number decided for } \\
\text { plaintiff in parentheses) }\end{array}$ & $2(1)$ & $18(7)$ & $26(12)$ & $16(5)$ & $62(25)$ \\
\hline $\begin{array}{l}\text { Number known appealed } \\
\text { (number known to have } \\
\text { overturned original decision } \\
\text { in parentheses) }\end{array}$ & $2(0)$ & $4(0)$ & $3(1)$ & 0 & $9(1)$ \\
\hline Total kepentingan cases & $4^{*}$ & 3 & 7 & 8 & 22 \\
\hline $\begin{array}{l}\text { Number in which decision } \\
\text { known (number decided for } \\
\text { plaintiff in parentheses) }\end{array}$ & 0 & $\begin{array}{c}0 ; \\
\text { one settled } \\
\text { before trial } \\
\end{array}$ & $5(2)$ & $8(0)$ & $13(2)$ \\
\hline Number known appealed & NA & NA & 0 & 0 & 0 \\
\hline Total PHK cases & $179^{* *}$ & 204 & $230^{\star \star \star *}$ & 194 & 807 \\
\hline $\begin{array}{l}\text { Number in which decision } \\
\text { known (cases decided for } \\
\text { plaintiff in parentheses) }\end{array}$ & $\begin{array}{c}20 \\
(12)\end{array}$ & $\begin{array}{c}156 ; \\
\text { including } \\
8 \text { settled } \\
\text { before trial } \\
\quad(31)\end{array}$ & $\begin{array}{c}151 ; \text { including } \\
16 \text { settled } \\
\text { before trial } \\
\text { and } 15 \\
\text { transferred to } \\
\text { other courts' } \\
\text { jurisdiction } \\
(80) \\
\end{array}$ & $\begin{array}{l}130 \\
(77)\end{array}$ & $457(200)$ \\
\hline $\begin{array}{l}\text { Number known appealed } \\
\text { (appeals known to have } \\
\text { overturned original decision } \\
\text { in parentheses) }\end{array}$ & $5(2)$ & $10(3)$ & $22(4)$ & $3(0)$ & $35(9)$ \\
\hline $\begin{array}{l}\text { Total "other" cases (e.g., conflicts } \\
\text { involving unions or cases with } \\
\text { basic details missing) }\end{array}$ & 0 & 2 & 2 & 44 & 48 \\
\hline
\end{tabular}

* Includes one case deemed both hak and kepentingan

** Includes two cases deemed both hak and PHK

${ }^{* * *}$ Includes eleven cases deemed both $h a k$ and PHK 
Surabaya's PHI began accepting cases in 2006 and handles a relatively small number of cases. There were never more than three hundred in any given year, compared with more than four thousand-roughly 3,500 criminal and more than six hundred civil-at Surabaya's Pengadilan Negeri. These factors made data collection, by copying basic information from the registers into a notebook in the clerks' office, relatively manageable.

Table 2 (previous page) presents the basic outlines of the data from the registers. The PHI's case load steadily increased, from 192 in 2006 to 274 in 2009, but not at such a high rate as might have been anticipated. Also, in keeping with the history of the P4 system, more than 80 percent of all cases filed since the court's inception revolved around PHK, while very few were related to kepentingan or union representation. Of the forty-eight cases in the "other" category, only four dealt with unions, the restmostly from the latter months of 2009-were missing basic data, as full information had not yet been entered into the register at the time of my fieldwork.

Table 3: Basic Data on Bandung PHI Cases, January 2006-April 2009

\begin{tabular}{|l|c|c|c|c|c|}
\hline & $\mathbf{2 0 0 6}$ & $\mathbf{2 0 0 7}$ & $\mathbf{2 0 0 8}$ & $\begin{array}{c}\text { 2009 } \\
\text { (through } \\
\text { April) }\end{array}$ & $\begin{array}{c}\text { Total } \\
\text { 2006-09 }\end{array}$ \\
\hline $\begin{array}{l}\text { Total cases filed (cases } \\
\text { transferred from P4D }\end{array}$ & $250(125)$ & 196 & 190 & 71 & 707 (125) \\
\hline Total hak cases & 3 & 20 & 23 & 3 & 49 \\
\hline Total kepentingan cases & 4 & 2 & 7 & 3 & 16 \\
\hline Total PHK cases & 118 & 174 & 160 & 65 & 517 \\
\hline Total decided & 142 & 163 & 128 & 47 & 480 \\
\hline $\begin{array}{l}\text { Total cases withdrawn } \\
\text { or settled }\end{array}$ & 69 & 45 & 34 & 15 & 163 \\
\hline $\begin{array}{l}\text { Total pending at year's } \\
\text { end (sisa) }\end{array}$ & 39 & 27 & 55 & 64 & 185 \\
\hline $\begin{array}{l}\text { Total appellate petitions } \\
\text { filed (number of appeals } \\
\text { withdrawn in } \\
\text { parentheses) }\end{array}$ & $51(4)$ & $98(18)$ & $79(8)$ & $39(4)$ & $267(34)$ \\
\hline
\end{tabular}

* This was a mostly one-off initiative to close the P4 system known as "Pelimpahan P4D."

Source: Pengadilan Hubungan Industrial pada Pengadilan Negeri Klas IA Bandung [The Special Court for Industrial Relations at the Bandung Class 1A Court], Bandung, http:/ / www.pn-bandung.go.id/page/ profil-phi, Tables 1-13, a pdf document dated May 2009, last accessed November 22, 2012. 
Most cases received by the Surabaya PHI seem to have been brought by workers or their representatives, rather than by employers seeking simple permission for dismissals. This was in marked contrast to the dynamic of the P4D system as revealed in the South and Central Kalimantan decision data. While the success rate for worker plaintiffs was slightly higher for PHK cases than for the second leading category (hak), it was not very significantly higher (roughly 43 percent versus 40 percent). Surprisingly, according to the register data, very few cases were appealed. This is odd, given the streamlined appellate procedure for PHI cases, anecdotal reports, and a widespread conventional wisdom among analysts and managers that many (perhaps most) PHI rulings are appealed. It is, of course, possible that data from the registers are simply incomplete.

Similar general trends are apparent in the basic quantitative data published by Bandung PHI, summarized in Table 3 (previous page). There, PHK disputes constituted 89 percent of the total caseload (exclusive of the 125 cases transferred over from the P4D upon the PHI's inception), with significantly more hak cases (8 percent) than suits over kepentingan (3 percent of the total cases). The broadly congruent patterns of case filings and court work in East and West Java-two of Indonesia's largest and most important industrial provinces-suggest that what I observed in Surabaya was more likely representative of national-level tendencies than a locally specific aberration.

\section{Processes Apparent in Surabaya Case Files}

Gathering qualitative data from case files was in some ways easier, but more hitand-miss, than perusing the registers. I was given full access to files I requested that were available on hand in the Surabaya court's archive. My strategy was to select cases from the register essentially at random within each frequently occurring category (PHK, hak, and kepentingan), with an aim of choosing samples broadly representing each. Labor union disputes were adjudicated so seldom that I simply requested every file I could identify as such. I also deliberately over-selected and requested files of cases that had been appealed to the Supreme Court. Many files turned out to be missing or in use by the court (and thus not available). Others were nearly empty or otherwise obviously incomplete. Finally, many files for cases that had been appealed did not contain all the appellate filing documents or the Supreme Court's decision (as they should have). Never, though, did I get the sense that this was due to anything other than insufficient staffing and poor archival skills on the part of the court clerks.

I was able to review nineteen case files thoroughly: twelve from cases involving PHK, one hak and PHK, four hak, and two kepentingan. Rather than simply reviewing these by each issue involved, it is more useful to discuss cases that support or call into question processes of judicialization, forum shopping, and bureaucratic competition, as well as those that might suggest none of those three processes was at work, or that might support alternative dynamics. I supplement each segment with cases from the NGO collection discussed earlier from around the archipelago to highlight the degree to which these qualitative findings may be nationally present-rather than locally idiosyncratic-phenomena. 


\section{Judicialization}

In these cases, we see the PHI acting as seems to have been intended under Law 2.2004-as an impartial arbiter in labor disputes, taking into consideration both employer and trade unionist perspectives, and adjudicating cases according to rules and procedures formalized in Law 2.2004 and Law 13.2003. Not surprisingly, many cases in which we can observe this dynamic are relatively simple and straightforward PHK suits.

In Case 127 from 2007, ${ }^{80}$ for example, a group of twenty-seven metal workers in Malang easily persuaded the PHI to enforce provisions of Law 13.2003 upon their intransigent former employer. The plaintiffs sued for back wages and severance after all were dismissed in August 2006, after two years on the job. Their employer argued that the company's contracts with the employees took precedence over general provisions of Law 13.2003 and that the firm had already paid out generous end-ofcontract bonuses, though witnesses for the plaintiffs disputed this. Eventually, the PHI ruled that the workers were due roughly 75 percent more severance money than they had received. The employer appealed to the Supreme Court, the result of which was still pending when I reviewed the file. Overall, this case depicts the PHI applying the law in an impartial and clear manner that also happens to have been beneficial for the workers who brought the case.

Another PHK case involved deception by an employer seeking to dismiss a bus driver, whose route was being cut. ${ }^{81}$ The PHI was able to identify this problem, pass judgment against the bus company despite the presence on the court of an ad-hoc judge from an employers' association, and impose a remedy appropriately grounded in Law 13.2003. In this case, the bus driver had worked for a company for fourteen years, driving the same Patas bus on the same route without any problems. He was sent home, however, when his employer said his bus needed repairs. Eight months following this dismissal, the company had given the driver's job to someone else and refused to hire him back. At that point, the driver sought mediation from the Manpower Bureau in Pasuruan.

The Manpower Bureau first failed to notify the company or call for it to send a representative to mediation meetings. Then, when finally called, the company's representative failed to appear. So the Manpower Bureau issued a letter ordering the company to take the driver back. After the company refused, the Manpower Bureau demanded that it pay fifteen months of back wages and a severance package to the driver, but the company refused this as well.

This left the driver just one option, to take his case to the PHI, which investigated and found that service on his route had actually been cut. The claimed "repairs" on his bus were apparently only a crude deception. The PHI also discovered, though, that the company did offer to take the driver back, albeit in another capacity, and the driver had refused this offer. The driver was thus not entitled to severance pay. Still, the PHI required the company to pay him wages for eight months during which he was idled

${ }^{80}$ Case No. 127/ G/2007/PHI.SBY (file obtained from Surabaya PHI archive).

${ }^{81}$ Case No. 75/G/2006/PHI.SBY (file obtained from Surabaya PHI archive). 
by the "repairs." The company appealed to the Supreme Court, but its appeal was rejected.

Interestingly, two cases from Southeast Sulawesi bear strong similarities to the bus driver's case. ${ }^{82}$ In those cases, mechanics at a ferry company were placed on involuntary leave. In the first of these cases, the company replaced a worker with a new employee without first terminating him formally; in the second, a different worker was placed on long-term leave while the boats he had maintained were overhauled. In both cases, the employer was ordered to pay back wages and ensure that the workers could return to their original posts.

The PHI's role as arbiter of the law on PHK issues sometimes extended into the terrain of union activities and rights, even when these were not formally part of the suit. For example, in one case from Sidoarjo, the PHI stepped in to protect the rights of union activists who had been fired for their organizing activities at a printing company. ${ }^{83}$ The three workers concerned, all union activists in the plant for Komisariat Serikat Buruh Sejahtera Indonesia, filed suit against their employer after they were dismissed (without severance payments), allegedly for abandoning their posts.

The workers maintained that their dismissals were, in fact, related to problems in the factory that stemmed from management's impromptu decision to pay wages via a Bank Mandiri ATM. After work stopped for thirty minutes-during which the plaintiffs claimed they explained the new procedures to rank-and-file workersmanagement became wary, withdrew plans for the ATM payment system, and summoned the union leaders to a meeting. At the meeting, the workers complained of perceived attempts by management to block union activities. In court, they claimed to have received letters of dismissal the following day.

The printing company argued that the workers had been suspended (skorsing) prior to their dismissals, but had never requested to return to their posts-that they had resigned de facto. The defendant also challenged the plaintiffs' legal representatives (lawyers from their union) because of ongoing negotiations and disputes between the firm and the union. In the end, the PHI ruled in favor of the workers and ordered the company to pay them severance, as well as back wages for the time in which their case was being processed. The employer appealed, but the Supreme Court upheld the PHI's decision, though it did reduce the mandated severance payments.

The dynamics of the Sidoarjo case are also similar to another from Banten. ${ }^{84}$ In that case, the management of a kitchenware manufacturing plant sought to dismiss several employees for engaging in an allegedly illegal work stoppage. The workers had taken approximately fifteen minutes to gather and listen to instructions and an explanation of new rules by management. After this, they were also suspended and then terminated. The Serang PHI, like its Surabaya counterpart, eventually decided that the workers were entitled to be re-employed in their old positions and receive back wages,

${ }^{82}$ Cases No. 2/G/2006/ PHI.Kendari and No. 3/G/2006/ PHI.Kendari (decision documents reproduced in Tjandra and Pangaribuan, Kompilasi Putusan, pp. 430-47, 448-69).

${ }^{83}$ Case No. 24/G/2008/PHI.SBY (file obtained from Surabaya PHI archive)

${ }^{84}$ Case No. 44/G/2006/PHI.Serang (Banten) (decision document reproduced in Tjandra and Pangaribuan, Kompilasi Putusan, pp. 598-627). 
but only if they followed proper civil procedure and filed formal countersuits (gugatan balik, or rekompensi).

One of the earliest cases heard in Surabaya's PHI, involving hak and kepentingan, in addition to PHK, is a good example of judicialization. ${ }^{85}$ Five workers sued one of Indonesia's largest manufacturers of kretek (clove cigarettes), claiming that they had been hired in 2005 but denied a contract and unlawfully deprived of protection (as legitimate employees) from being wrongly dismissed. In this case, the five workers filed suit against their employer in Kediri, claiming that their requests for written contracts, which had been denied (even after the Kediri Manpower Bureau had issued a formal letter calling on the firm to resolve this problem), led the company to dismiss them unlawfully.

After receiving the Manpower Bureau's letter, the company chose mediation to resolve the standoff, but no agent or representative of the manufacturer appeared, even when called to meetings by the mediator. After receiving a judgment letter in their favor from the Manpower Bureau, the workers brought their case to the PHI. It was revealed during the PHI proceedings that four of the plaintiffs held law degrees, and all five had been managers within the firm's industrial relations division. The defendant (the plant director) never appeared nor did he send a representative when summoned by the PHI, and so the plaintiffs won their suit without contest and the PHI issued a decision ordering the company either to take them back or to pay them severance. The file contained no documents related to any appeal, but one can imagine the defendant may well have appealed, especially given the size of the firm and the relatively high profile of the disgruntled former employees.

As we can see, judicialization has not proceeded easily. Still, the Surabaya PHI clearly made significant efforts both to institutionalize a triadic dispute resolution framework for labor relations cases and to extend the power of the judiciary into previously ungoverned or administratively regulated spheres of social interaction.

\section{Forum Shopping}

In part because the PHIs' respective substantive and territorial jurisdictions are relatively well defined, I found few clear examples of forum-shopping behavior. There were still some, however. In one case of apparent forum shopping, a woman under investigation for embezzlement sued her former employer (a large corporation based in Jakarta, owned by a parent company in Singapore, in whose Surabaya branch she had worked) for wrongfully dismissing her, believing apparently that the PHI might present a more favorable venue than the Pengadilan Negeri. ${ }^{86}$ The plaintiff was fighting a pending criminal charge, but the suit she tried to press in the PHI was also tantamount to a civil suit for unlawful behavior (perbuatan melawan hukum, PMH) - not covered by the definition of PHI jurisdiction in Law 2.2004.

Despite the dubious validity of her case as a PHK issue, she was able to get a mediation decision in her favor from the Surabaya Manpower Bureau, but she rejected

\footnotetext{
${ }^{85}$ Case No. 36/G/2006/PHI.SBY (file obtained from Surabaya PHI archive).

${ }^{86}$ Case No. 116/G/2007/PHI.SBY (file obtained from Surabaya PHI archive).
} 
it as insufficient. In her filing with the PHI, the plaintiff claimed that managers and supervisors in both Surabaya and Jakarta were, in fact, corrupt (the plaintiff presented bank statements to illustrate this) and had framed her for embezzlement to cover up their own misdeeds. Her dismissal thus amounted to illegal behavior, and she demanded damages to cover debts she said she incurred by helping her superiors cook their books, in addition to normal severance.

Her employer disputed the bank statements and other basic facts, but argued more fundamentally that, as a PMH suit, the case did not belong in the PHI. The company also claimed that the plaintiff's attorney was an active-duty naval officer, and thus prohibited from representing clients in court. The case should thus either be dismissed or remanded to the Pengadilan Negeri for adjudication as a PMH suit, according to the company.

The PHI ruled for the plaintiff and ordered the company to pay her severance as well as back wages for the time during which her case was being adjudicated. Not surprisingly, the defendant appealed. The Supreme Court made clear that any issues related to allegations of embezzlement were a criminal issue under investigation by the police, concerning which charges were likely pending, and did not have any place in the PHI. The plaintiff thus could not ask for back wages or press a PHK claim unless and until she were cleared of criminal responsibility in the embezzlement case. On the $\mathrm{PMH}$ claims and legal representation issues, the Supreme Court's decision was less clear, deeming her suit a $\mathrm{PHK}$, and not $\mathrm{PMH}$, case, and ruling that the woman was indeed entitled to a modest severance package.

One of the clearest cases of territorial forum shopping I was able to track down from beyond Surabaya involved trade unions and a Japanese tire manufacturer-in a hak and kepentingan dispute over whether or not cost-of-living adjustments (perbaikan taraf hidup, or PTH) ought to be included as a component of wage increases in collectively bargained contracts between the unions and the firm. The company brought a suit in Central Jakarta, site of its head offices for Indonesia, claiming it never agreed in writing to such adjustments and that they therefore need not be included when calculating wages. ${ }^{87}$ The unions filed a parallel suit in Bandung, as the company's Indonesian tire factories were located in the West Java cities of Bekasi and Karawang, claiming that PTH adjustments had always been included by custom and that this pattern, once established, should be legally enforceable even without a written agreement. $^{88}$

The contracts in question covered workers employed both at the downtown Jakarta offices and at the suburban manufacturing plants in West Java. Because of ambiguities regarding which PHI should have jurisdiction in such a case, both parties were able to see their suits over the same case go forward in separate courts. Perhaps predictably, the courts ruled differently, with Central Jakarta's siding with the company and West Java's (where the unions had won a mediation claim with the Manpower Bureau just before filing the suit) deciding in favor of the unions. Unfortunately, neither the two

${ }^{87}$ Case No. 143/ PHI.G/2007 / PN.JKT.PST, decision document reproduced in Tjandra and Pangaribuan, Kompilasi Putusan, pp. 633-85.

${ }^{88}$ Case No. 90/G/2007/PHI.BDG, decision document reproduced in Tjandra and Pangaribuan, Kompilasi Putusan, pp. 686-735. 
PHIs nor the Supreme Court could use the case to establish a clear precedent regarding PHI jurisdiction. Instead, the tire manufacturer's Japanese parent company intervened preemptively from Tokyo to ensure that the workers received sufficient wage increases to stave off any possible strike action. ${ }^{89}$

Forum shopping may be a difficult pathology to ward off as PHIs take shape. Various authorities, including the Supreme Court, however, have engaged publicly to rein it in, and flagrant or blatant forum shopping appears to have been relatively rare in the sample cases I reviewed. The net result of the current rules on jurisdiction and the limited forum shopping opportunities that do exist, however, may well serve the political and economic interests of firms and the state better than those of workers.

\section{Bureaucratic Competition}

I did not find many cases of Mertha-type virtuous bureaucratic competition. There were more that seemed to follow a Migdal-type pattern, but even these were not always clear-cut. One interesting case of apparent bureaucratic competition involved workers dismissed from a rural wood-furniture factory. ${ }^{90}$ In this case, the PHI seems to have overstepped its boundaries to extend statutory rights to workers whose status and actions were not fully protected.

This was a complex dispute, involving both hak and PHK issues, which went through an appeal to the Supreme Court. Despite the questionable labor practices and uncooperative behavior of the defendant during the adjudication process, the Supreme Court sided with the employer and overturned upon appeal the PHI's original decision to grant the workers compensation (penggantian hak) and back wages. This decision was based on a finding that the workers' dismissal was tantamount to a lockout and that seasonal workers enjoy reduced protections. Also of note is that the East Java Metal Workers' Union became involved, filing an appellate brief (kontra memori kasasi) on behalf of the workers, despite their marginal status as seasonal rural workers.

There are a few cases in which it seems the PHI may have gone against earlier mediation or arbitration results to assert its independence or authority. In one such dispute, the court adjusted an earlier remedy to eliminate the requirement to pay back wages and reduce the severance due the plaintiff, who had been dismissed by his employer after an altercation with a customer. ${ }^{91}$ Neither side was pleased with this outcome-indeed, the reasoning of the court was not explained very clearly-yet the Supreme Court upheld the decision on appeal.

There are few clear cases of bureaucratic competition. Workers and unions have sometimes complained of what we might call "negative competition" among institutions keen to ignore them or avoid responsibility for addressing their grievances, and the opening of more institutional channels, perhaps ironically, has drastically increased the amount of time needed to resolve disputes or address grievances. Still,

\footnotetext{
${ }^{89}$ Tjandra and Pangaribuan, Kompilasi Putusan, explanatory notes on pp. 631-32.

${ }^{90}$ Case No. 130/G/2006/PHI.SBY (file obtained from Surabaya PHI archive).

${ }^{91}$ Case No. 168/ G/2007/ PHI.SBY (file obtained from Surabaya PHI archive).
} 
the newly reconfigured labor dispute resolution institutions appear to be establishing important boundary markers between their spheres of authority.

\section{Something Completely Different?}

There are a number of cases that suggest none of the three basic logics noted above. Some of these, especially earlier cases, suggest possible other dynamics-such as confusion or lack of knowledge concerning the PHI's mandate and jurisdiction, including regarding what sorts of suits could be brought. But even by 2009 , judges and lawyers were often unclear on key points.

In the earliest case I examined, a disabled security guard (who was also a veteran of the 1945 independence struggle) sued his employer for unlawfully dismissing him. ${ }^{92}$ He claimed he was asked to resign (and then denied severance) after suffering a stroke and becoming disabled. His employer refused one form of mediation and then failed to appear when called for another. Before the case reached the PHI, the Surabaya Manpower Bureau issued a letter ordering the employer to pay the guard severance, but this was ignored.

What stands out in this case is the degree to which both sides seem not to have focused on key basic facts. The plaintiff never established that his departure from the company was mandatory. The defendant never made the case that the plaintiff had resigned, but instead called a witness to testify that the company had a policy against paying (legally mandated) severance, presented documents to the same effect, and claimed the plaintiff had caused substantial damage to company property (but never argued that he had been dismissed with cause). The PHI appeared confused and unable to apply key provisions of Law 13.2003. Ultimately, it took the Supreme Court to decide, upon appeal, that the plaintiff was, in fact, owed severance pay because his departure was never established as either a resignation or dismissal for cause.

In some other cases, one or even both parties failed to appear in court on multiple occasions, either because they were never properly called or perhaps in a deliberate challenge to the PHI's authority. In one such case, a car loan service officer filed suit against his former employer (a large national corporation) for wrongful dismissal. ${ }^{93}$ The plaintiff had gone through mediation and filed a decision letter in his favor from the Surabaya Manpower Bureau when he brought his suit. All his documents were in order, and the defendant's were incomplete. But he then failed three times to appear in court, causing the PHI to dismiss his case on the third occasion with only the defendant present.

A much more complicated case was also dismissed, but for different reasons. ${ }^{94}$ In this case, twenty-five workers (assisted by a labor lawyer) sued their former employer (a large furniture fittings and accessories manufacturer in Surabaya) for allegedly dismissing them improperly after a series of acrimonious shop-floor interactions. The workers claimed that six among them were fired without proper notices being issued.

${ }^{92}$ Case No. 19/G / 2006/PHI.SBY (file obtained from Surabaya PHI archive)

${ }^{93}$ Case No. 50/G / 2006/PHI.SBY (file obtained from Surabaya PHI archive).

${ }^{94}$ Case No. 91/G/2007/PHI.SBY (file obtained from Surabaya PHI archive). 
Their employer claimed they had been absent from work (for three days, absences for which the workers said they had permission) and encouraged others to lodge complaints with the Manpower Bureau or even to strike. The other nineteen workers were summarily dismissed shortly after the first six were terminated, allegedly without any explanation or justification. The workers said that they had sought mediation, but management never appeared when called by the Manpower Bureau.

The defendant confirmed that there had been labor strife at the factory, but alleged that the plaintiffs had tried to coerce managers into working with a union that did not formally represent workers in the plant. The union had brought claims against the company to the East Java P4D and had won the case. The defendant had appealed to the P4P in January of 2006, just as the P4 system was giving way to the PHI, but the case was not decided before the PHI suit came to trial in July 2007. The defendant argued the PHI could not hear the case while the P4P decision was still pending (i.e., the suit was premature).

Both sides had substantial documentary evidence to back up their positions, but three witnesses were also called to testify. Two of these were workers at the plant. One had participated in a strike alongside the plaintiffs in 2005 over the defendant's alleged failure to pay wages in full, but she testified there were no ringleaders even though she claimed the workers had obtained a police permit. After the strike, all workers were retained and allowed to return to work, though the witness resigned voluntarily shortly after. She knew the plaintiffs had filed complaints, but had no other knowledge of the process or results. The second worker to testify knew even less about the case, only that the plaintiffs were permanent workers, while he was temporary. He said he left the firm when his contract expired and knew nothing about any goings-on afterwards. The last witness was a mediator from the Manpower Bureau, who confirmed that the defendant had failed to appear and that the plaintiffs had presented him with comprehensive documentary evidence in support of their version of the facts of the case. He also said the defendant told him explicitly that he would not appear unless and until the appellate decision from the P4P in the earlier filing were received. Finally, he maintained that the earlier P4 filing and the current PHI case were over separate issues.

The PHI ruled that the P4 case and the current suit were indeed separate issues. But the judges did not rule on the merits of the plaintiffs' claims. Instead, they dismissed the case as "unclear" (kabur), based on problems with the form of the original filing, which had listed "Agus Sudiono et. al. [twenty-five people] workers" at the defendant's firm. The filing also failed to itemize the severance payments sought for each individual, stating instead that Rp.408,882,500 was sought for the whole group. The plaintiffs appealed the PHI's dismissal, but the Supreme Court upheld the PHI's reasoning and imposed additional court costs on the plaintiffs.

In a different case, the PHI seemed confused but defaulted to awarding damages to an aggrieved worker when neither side presented particularly strong evidence. ${ }^{95}$ The plaintiff-a worker fired by the Indonesian Music Foundation in Surabaya-made strong allegations that he and others had been dismissed improperly, though he did

${ }^{95}$ Case No. 56/G/2008/ PHI.SBY (file obtained from Surabaya PHI archive). 
not support them well with evidence. The defendant did not present a forceful counter-argument and failed to show that the worker had either resigned or been fired for cause. The PHI deemed the employee's dismissal illegal and awarded generous damages and back pay and required that the foundation hire the plaintiff back. After the defense appealed, the Supreme Court amended the decision to remove the requirement to rehire the plaintiff and adjusted the total severance package downward.

Finally, in a less clear case, the PHI found for the plaintiff when the defendant presented an argument that perhaps should have won the day, and which the court almost certainly should have addressed carefully-specifically that the issue in play was not properly defined and that it mixed elements of hak and kepentingan. ${ }^{96}$ Still, the letter of Law 2.2004 is vague on exactly how this dispute should have been handled. The plaintiff, a disgruntled employee of a business services firm in Surabaya, sued his manager over a demotion (and pay cut) he had received. The plaintiff claimed to have received a "third warning" letter just prior to his demotion, without ever having received a first or second warning. He also maintained that the workplace rules and conditions of employment in the firm were not sufficiently clear.

The defendant said the suit was unclear (kabur and kurang jelas) because the plaintiff lacked comprehensive evidence of the full picture. He also argued that the suit mixed kepentingan (issues about the firm's workplace rules and whether or not these were actionable) with hak (concerning the specific terms of the plaintiff's contract and whether he was entitled to compensation for having received less pay than he'd been promised). The PHI ruled for the plaintiff and ordered the defendant to restore his old position and salary, as well as to pay back wages. It accepted his evidence (from his contract) of the salary he'd be promised and (from other documents) of the salary he'd received after his demotion, without considering the questions of whether the demotion and pay cut were reasonable and whether the workplace rules (or lack thereof) were actionable.

These cases do not show conclusively that any alternative logic or dynamic is in play in Surabaya, or throughout Indonesia. But they do raise doubts as to the applicability of judicialization, forum shopping, and bureaucratic competition for understanding the work of the PHI. With more in-depth analysis of a wider sampling of cases, it may be possible to develop a new lens or framework for better understanding how Indonesia's new labor dispute resolution institutions are coming into their own and the effects they are having on Indonesian politics and society.

\section{Conclusion: Implications for Indonesian Legal Reform and Labor Politics}

The picture for Indonesian legal reform presented by the PHIs in their first four years is decidedly mixed. On the one hand, Indonesia is among the leaders across the developing world in codifying labor rights, making them "legible" in court, and enhancing the political and social position of labor (at least on paper), even as it has eroded in most other countries. On the other hand, the system remains inchoate,

${ }^{96}$ Case No. 121/G/2008/PHI.SBY (file obtained from Surabaya PHI archive). 
poorly utilized, little understood, and in occasional tension with other organs of the Indonesian state as well as its own history.

Many ad hoc judges have been paid salaries only sporadically, if at all. ${ }^{97}$ Many PHI judges, professional and ad hoc alike, are also said to be incompetent, lacking even a thorough knowledge of relevant Indonesian jurisprudence ${ }^{98}$ There have also been at least a few high-profile cases of corruption, including a recent sensational bribery scandal involving an ad hoc PHI judge in Bandung. ${ }^{99}$

Inconsistency, even within one court, is a frequently encountered problem in the PHIs' operations. ${ }^{100}$ Such inconsistency can erode public confidence in the new court system as an institution. Until standards become more uniform and decisions more enforceable, it is unlikely that the PHI courts will be able to perform any more meaningful or influential role in Indonesian politics and society, which means they will remain only a slight improvement over the P4 system.

On this last point, the PHIs are able to adjudicate a much broader array of rights and claims than the $\mathrm{P} 4$ institutions they replaced. The rules governing them are more favorable to labor, and workers are permitted, even encouraged, to file cases proactively. The PHIs are also meant to be independent of the executive authority of the state and to provide a more neutral venue for dispute resolution. Despite these advantages, they have not clearly or consistently enhanced workers' power in the political arena.

In a less advantageous reversal of the P4 norms, workers must now take the initiative to file PHK cases. Whereas employers used to be required to petition the P4D or P4P for approval to dismiss employees, the onus is now on workers to petition the PHI to block dismissals. Even when cases are brought, workers must pursue a lengthy and uncertain process before finally receiving a theoretically enforceable judgment, which is by no means always in their favor. Expanded opportunities for adjudication have produced at least the potential for increased uncertainty, longer processing times, and a greater chance that plaintiffs will simply be ignored.

Much work remains to be done before we can confidently outline even the basic contours of Indonesia's PHI. But already a number of key issues and themes are starting to emerge. By continuing to think systematically about the political and legal dynamics and processes that might underlie their functioning, we can come to a better understanding both of how the PHIs work, and also of the roles they are likely beginning to play in the changing political and social landscape of labor relations in post-New Order Indonesia.

\footnotetext{
${ }^{97}$ Rajagukguk, "The New Indonesian Labor Court," p. 2.

${ }^{98}$ Miranda Fajerman, Report: Training Needs Assessment for Industrial Relations Court Judges (Jakarta: International Labour Organization, 2011), p. 40; Rajagukguk, "The New Indonesian Labor Court," p. 13.

${ }^{99}$ Erick P. Hardi, "Buruh Tuntut Hakim Imas Dianasari Divonis Secara Adil" [Workers Demand Judge Imas Dianasari be Judged Fairly], Tempo January 17, 2012, http://www.tempo.co/ read/ news / 2010/05/01 /173244713/Buruh-Tuntut-Mafia-di-Pengadilan-Hubungan-Industrial-Diberantas, accessed September 24, 2012; Erick P. Hardi, "Terima Suap, Hakim Imas Divonis 6 Tahun Bui" [For Taking Bribes Judge Imas Sentenced to Six Years in Jail], Tempo, January 30, 2012, http:// www.tempo.co/read/ news/2012/01/30/ 178380525/ Terima-Suap-Hakim-Imas-Divonis-6-Tahun-Bui, accessed September 24, 2012.

${ }^{100}$ Fajerman, Report, p. 23.
} 